\title{
GAMBARAN PERILAKU PENGASUHAN REMAJA OLEH ORANG TUA DI LINGKUNGAN KELUARGA
}

Jurnal Pendidikan Luar Sekolah

http://kolokium.ppj.unp.ac.id/ Jurusan Pendidikan Luar Sekolah

Fakultas Ilmu Pendidikan

Universitas Negeri Padang

Sumatera Barat, Indonesia

Volume 5, Nomor 2, Oktober 2017 DOI: $10.24036 /$ kolokium-pls.v5i2.26

\section{Efriza Anggraini ${ }^{1,2}$}

1Jurusan Pendidikan Luar Sekolah Fakultas Ilmu Pendidikan Universitas Negeri Padang

2Email: efrizaanggrainni94@gmail.com

\begin{abstract}
ABSTRAK
Penelitian ini dilatarbelakangi oleh tingkah laku anak yang baik, pribadi yang baik, sifat ramah tamah dan juga sifat sopan santun kepada semua orang. Tujuan penelitian ini adalah untuk mengungkapkan gambaran peran orang tua yang ditinjau dari kontrol, dukungan, komunikasi, kedekatan, dan pendisiplinan terhadap remaja dalam perilaku pengasuhan di Jorong Tanjung Betung, Kecamatan Rao Selatan, Kabupaten Pasaman. Jenis penelitian adalah deskriptif kuantitatif. Populasinya adalah orang tua yang memilki remaja usia 13-20 tahun sebanyak 65 orang dengan sampel 24 orang. Teknik pengambilan sampel menggunakan cluster random sampling. Teknik pengumpul data adalah angket dengan alat pengumpul data berupa daftar pernyataan. Teknik analisis data menggunakan perhitungan persentase. Hasil penelitian menunjukkan perilaku pengasuhan oleh orang tua terhadap remaja sangat baik, terlihat dari tingginya persentase jawaban selalu dan sering. Disarankan kepada orang tua agar bentuk perilaku pengasuhan pada remaja lebih ditingkatkan lagi.
\end{abstract}

Kata Kunci: Perilaku Pengasuhan, Remaja

\section{PENDAHULUAN}

Bentuk dari pendidikan informal adalah pendidikan dalam keluarga. Pendidikan keluarga merupakan pendidikan yang paling pertama dan utama kali kita temui ketika kita dilahirkan yang akan berlangsung sepanjang hayat. Pernyataan itu dipertegas oleh Soelaiman (2004), yang mengemukakan bahwa pendidikan informal ialah pendidikan yang diperoleh seseorang dari pengalaman sehari-hari, dengan sadar maupun tidak sadar sejak seseorang lahir sampai meninggal.

Dengan adanya pengetahuan dan pemahaman diperoleh melalui pendidikan orang tua akan mengasuh anak dengan baik dan anak dapat merubah perilaku anak sesuai dengan yang diterapkan. Masa remaja sering dikenal dengan masa pencarian jati diri (ego identity). Remaja adalah generasi yang berumur 12-25 tahun (Resty, 2016). Apabila mereka bersekolah, batasannya adalah mereka yang belajar di tingkat SMP, SMA, dan tahun-tahun awal perguruan tinggi. Salah satu sikap yang diharapkan sudah ada pada masa remaja adalah remaja mampu berperilaku moral. Perilaku moral adalah nilai-nilai perbuatan perilaku yang baik dan buruk yang berhubungan dengan kelompok sosial sesuai dengan nilai-nilai masyarakat yang timbul dari hati nurani dan bukan merupakan paksaan yang berasal dari luar dirinya. 
Perilaku moral anak dapat dibentuk melalui pendidikan dan mengupayakan pengasuhan yang kompoten bagi perkembangan perilaku anak sesuai yang diterapkan. Menurut Vinayastri (2015), pengasuhan adalah interaksi orang tua dengan anak dalam keluarga untuk mendidik, membimbing dan mengajarkan anak dalam tujuan tetentu yaitu berperilaku. Bentuk-bentuk perilaku pengasuhan yang terdapat dalam relasi orang tua dan anak yaitu kontrol, dukungan, komunikasi, kedekatan, dan pendisiplin .

Dapat disimpulkan bahwa pendidikan dalam keluarga merupakan pengetahuan dan pemahaman upaya dari orang tua dalam mengasuh anak sehingga orang tua bisa memberikan contoh yang baik kepada anak dan membentuk perilaku anak yang sesuai dengan aturan hukum dan ajaran agamayang berlaku sehingga anak dapat membedakan mana yang baik dan yang buruk, benar dan salah.

Jorong Tanjung Betung merupakan salah satu jorong di Kecamatan Rao Selatan, Kabupaten Pasaman yang penulis lihat masih terdapat remaja yang bersekolah. Berikut adalah jumlah remaja yang ada di Jorong Tanjung Betung yang berumur 12-25 tahun, untuk lebih jelasnya dijabarkan melalui Tabel 1.

Tabel 1.

Jumlah Remaja di Jorong Tanjung Betung Pada Tahun 2015

\begin{tabular}{lllll}
\hline No. & Jenis Kelamin & Tingkat Sekolah & Jumlah & Total \\
\hline 1. & Laki-laki & SMP & 17 & \multirow{2}{*}{43} \\
& & SMA & 19 & \\
2. & \multirow{3}{*}{ Perempuan } & KULIAH/PT & 7 & \multirow{2}{*}{51} \\
& & SMP & 27 & \\
\hline & SMA & 20 & $\mathbf{9 4}$ \\
\hline
\end{tabular}

Sumber: Kantor Wali Tanjung Betung

Berdasarkan fungsi dan peranan pendidikan keluarga yang dikemukakan oleh Jailani (2014), penulis ingin mengetahui apakah remaja di Jorong Tanjung Betung sudah mampu memberikan pengalaman pertama masa kanak-kanak yang merupakan faktor penting dalam perkembangan pribadi anak, menjamin kehidupan emosional anak yang diliputi rasa cinta, simpati, suasana yang aman, tentram, suasana percaya mempercayai, menanamkan dasar pendidikan moral, memberikan dasar pendidikan sosial, dan peletakan dasar-dasar keagamaan. Maka penulis melakukan pengamatan pada tanggal 19-25 November 2015. Dari pengamatan yang penulis lakukan terhadap 65 dari 94 orang remaja, secara umum ratarata mereka telah mampu untuk menanamkan fungsi dan peranan pendidikan keluarga yang diberikan orang tuanya dengan baik.

Hal ini dibuktikan dengan observasi pada 2 Desember 2015 yang penulis lakukan dengan 45 orang remaja di Jorong Tanjung Betung. Dari hasil observasi secara umum diketahui remaja di Jorong Tanjung Betung telah mampu tumbuh dan berkembang sampai melepaskan diri dari ikatan keluarga, hal inilah keseimbangan jiwa di dalam perkembangan individu selanjutnya ditentukan. Dalam hal ini remaja sudah mampu menanamkan pengalamannya. Mereka juga mampu mengontrol emosi, tidak mudah terpancing untuk berkelahi dengan temannya serta lebih memilih untuk bermusyawarah dalam menyelesaikan masalah. Dalam hal ini, remaja sudah mampu menjamin kehidupan emosionalnya.

Selanjutnya pengamatan kepada 10 orang remaja mereka juga mampu bersikap dan berperilaku seperti berbicara dengan menggunakan kata-kata sopan dan lembut, tidak 
menggunakan nada yang tinggi, dan keras. Dalam hal ini remaja sudah mampu menanamkan dasar pendidikan moral. Mereka juga saling tolong menolong dalam membantu saudara atau tetangga yang sedang sakit, tertimpa musibah, gotong royong, dan menjaga ketertiban. Dalam hal ini remaja telah mampu memberikan dasar pendidikan sosial. Selanjutnya mereka juga mampu menjalankan ibadah seperti mengerjakan shalat atau pergi shalat berjamaah ke mesjid, mendengarkan khutbah atau ceramah keagamaan. Dalam hal ini mereka telah mampu dalam peletakan dasar-dasar keagamaan.

Untuk membuktikannya, penulis melakukan wawancara dengan Bapak Jorong Tanjung Betung, yaitu Bapak Syakban pada 2 Desember 2015. Beliau menjelaskan bahwa 10 orang remaja di Jorong Tanjung Betung ini telah mampu tumbuh dan berkembang dan tidak tergantung kepada orang lain. Menurut hasil wawancara penulis dengan Bapak Abdul Haris selaku Wali Nagari Tanjung Betung pada tanggal 3 Desember 2015, bahwa remaja yang berada di Jorong tersebut sudah ada perubahan perilaku moral yang meningkat baik dari pada sebelumnya, hal ini tidak terlepas dari kerja keras dan perhatian dari orang tua yang ingin membina moral remaja dengan baik.

Menurut hasil wawancara penulis kepada Bapak Syafrizal sebagai salah satu tokoh masyarakat di Jorong Tanjung Betung pada 3 Desember 2015. Beliau mengatakan bahwa di Jorong tersebut orang tua menanamkan nila-nilai agama kepada anak seperti mengajarkan anak untuk beribadah dan mengajarkan anak selalu untuk berbuat baik. Menurut hasil wawancara penulis dengan beberapa tetangga yang berada di Jorong Tanjung Betung pada 4 Desember 2015, mereka mengatakan bahwa remaja tersebut berperilaku moral itu terlihat dari kehidupan sehari-hari seperti mereka tidak mau membantah orang tua, dan mau mematuhi peraturan orang tua.

Dari pengamatan dan wawancara yang penulis lakukan, dapat disimpulkan secara umum bahwa faktor yang memengaruhi perilaku anak yang baik diduga oleh pengasuhan yang diberikan orang tua kepada anak di dalam keluarga. Hedyanti, Sudarmiatin, \& Utaya (2016) mengatakan bentuk-bentuk perilaku pengasuhan yang terdapat dalam relasi orang tua dan anak, yaitu: kontrol, dukungan, komunikasi, kedekatan, dan pendisiplinan.

Menurut Baldwin (dalam Lestari, 2012), menyatakan bahwa kontrol diartikan sebagai penekanan terhadap adanya batasan-batasan terhadap perilaku yang disampaikan secara jelas kepada anak dalam mengajarkan hal-hal yang benar. Menurut Baumrind (dalam Lestari, 2012), mengungkapkan bahwa kontrol yang otoritatif akan mendorong anak untuk mampu bersosialisasi dengan baik, punya inisiatif, dan mandiri. Kontrol sering diartikan sebagai mengawasi setiap kegiatan yang dilakukan oleh seorang anak dan memperhatikan perilaku anak. Apabila seseorang mendapatkan masalah atau kesulitan, maka seseorang tersebut membutuhkan dukungan dan dorongan dari keluarga serta lingkungan di sekitarnya, untuk mencapai otonomi atas diri sendiri. Menurut Thomas \& Rollins (dalam Lestari, 2012), menyatakan dukungan orang tua sebagai interaksi yang dikembangkan orang tua kepada anak yang dicirikan oleh perawatan, kehangatan, persetujuan, dan perasaan positif orang tua terhadap anak. Sehingga dengan adanya dukungan orang tua dapat membantu anak dalam menyelesaikan masalah, menentukan pilihan, memberikan nasihat kepada orang lain dalam pengambilan keputusan. Dukungan yang dapat diberikan oleh orang tua kepada anak adalah membuktikan atau melaksanakan keputusan yang telah diambilnya, mengatasi sendiri berbagai masalah yang muncul, mengembangkan kemampuan yang dimilikinya, serta belajar mengambil inisiatif. 
Ross (dalam Engkoswara \& Komariah, 2011), mendefinisikan komunikasi sebagai suatu proses menyortir, memilih, dan mengirimkan simbol-simbol sedemikian rupa, sehingga membantu penggemar membangkitkan makna atau respons dari pikirannya yang serupa dengan yang dimaksudkan oleh sang komunikator. Komunikasi dilakukan hendaknya menggunakan kata yang lembut dan sopan, mempunyai sifat keterbukaan antara anak dan orang tua (Muchith, 2015). Menjadi pendengar yang baik dan selalu membuka diri untuk berdialog dengan anak adalah langkah awal dalam mengakrabkan hubungan antara orang tua dan anak. Komunikasi yang dilakukan adalah orang tua berbicara menggunakan kata-kata yang lembut dan sopan, memilki keterbukaan kepada anak, rasa percaya dalam berkomunikasi, menjadi pendengar yang baik, dan kejujuran.

Kedekatan yang dilakukan oleh tua dan anak memberikan keuntungan secara tidak langsung, kedekatan orang tua dan anak memberikan keuntungan secara tidak langsung, seperti yang diungkapkan Rogers (dalam Lestari, 2012), yaitu bila tingkat kedekatan orang tua dengan anak tidak tinggi, maka remaja cenderung mempersepsikan pemantauan yang dilakukan oleh orang tua sebagai gangguan. Begitu juga sebaliknya, bila ada rasa saling percaya antara orang tua dan anak, maka remaja mempersepsikan pemantauan yang dilakukan orang tua kepada anak merupakan salah satu bentuk perhatian orang tua kepada anak.

Menurut Wayson (dalam Shochib, 2010), disiplin adalah suatu tata tertib yang dapat mengatur tatanan kehidupan pribadi dan kelompok yang berdasarkan pada nilai agama, nilai budaya, aturan-aturan pergaulan, pandangan hidup, dan sikap hidup yang bermakna bagi dirinya sendiri, masyarakat, bangsa dan negara. Disiplin timbul dari jiwa karena adanya dorongan untuk mentaati tata tertib tersebut. Makna kata disiplin dapat dipahami dalam kaitannya dengan latihan yang memperkuat, koreksi dan sanksi, kendali atau terciptanya ketertiban dan keteraturan dan system aturan tata laku (Elly, 2016). Di mana dalam pelaksanaan disiplin ini juga perlu suatu ganjaran atau hukuman dalam suatu penegakan disiplin tersebut dapat berjalan dengan maksimal.

Tujuan yang ingin dicapai pada penelitian ini adalah: (1) Menggambarkan kontrol yang dilakukan orang tua terhadap remaja di lingkungan keluarga, (2) Menggambarkan dukungan yang diberikan oleh orang tua terhadap remaja di lingkungan keluarga, (3) Menggambarkan komunikasi yang dilakukan oleh orang tua terhadap remaja di lingkungan keluarga, (4) Menggambarkan Kedekatan yang dilakukan orang tua terhadap remaja di lingkungan keluarga, dan (5) menggambarkan pendisiplinan yang dilakukan orang tua terhadap remaja di lingkungan keluarga.

\section{METODE}

Jenis penelitian ini adalah deskriptif kuantitatif. populasi dalam penelitian ini adalah orang tua remaja berusia 12-25 tahun yang menetap dan bekerja di Jorong Tanjung Betung pada tahun 2016 sebanyak 65 orang. Sampel dalam penelitian ini bersifat heterogen jika dilihat dari segi mata pencaharian. Untuk mempermudah dalam memahaminya, penulis uraikan pada Tabel 2. berikut ini. 
Gambaran Perilaku Pengasuban Remaja oleh Orang Tua di Lingkungan Keluarga

Tabel 2

Penarikan Sampel Berdasarkan Jenis Pekerjaan Populasi

\begin{tabular}{llcc}
\hline No. & Jenis Pekerjaan & Jumlah Populasi & Jumlah Sampel \\
\hline 1. & Petani & 40 & 16 \\
2. & Pegawai & 5 & 2 \\
3. & Pedagang & 15 & 6 \\
\hline & Jumlah & $\mathbf{6 5}$ & $\mathbf{2 4}$ \\
\hline
\end{tabular}

Sampel yang diambil adalah sebanyak 40\% dari masing-masing jenis populasi. Banyak sampel adalah 24 orang tua remaja di Jorong Tanjung Betung. Sumber data adalah orang tua dari remaja di Jorong Tanjung Betung sebanyak 24 orang. Adapun teknik yang digunakan dalam penelitian ini adalah kuesioner dengan alatnya angket.

Uji validitas dan reliabilitas menggunakan SPSS (Statistic Package and Service Solution) Windows 16. Hasil dari analisis uji coba instrumen, diperoleh bahwa semua item yang diuji cobakan pada 11 orang tua dari remaja di Jorong Tanjung Betung, Kecamatan Rao Selatan, Kabupaten Pasaman pada 17 Oktober 2016 dengan 41 soal dinyatakan valid karena $R_{\text {hitung }}>$ dari $R_{\text {tabel }}$, di mana $R_{\text {tabel }}$ adalah 0,602 untuk interval 95\% dan 0,735 untuk kepercayaan 99\%., dengan tingkat reliabelnya 0.962. Teknik analisis data yang digunakan adalah teknik statistik deskripsi dengan perhitungan persentase.

\section{HASIL PENELITIAN DAN PEMBAHASAN}

\section{Hasil Penelitian}

\section{Gambaran Kontrol Orang Tua terhadap Remaja di Lingkungan Keluarga}

Untuk melihat kontrol orang tua terhadap remaja, dapat dilihat dalam Gambar 1.

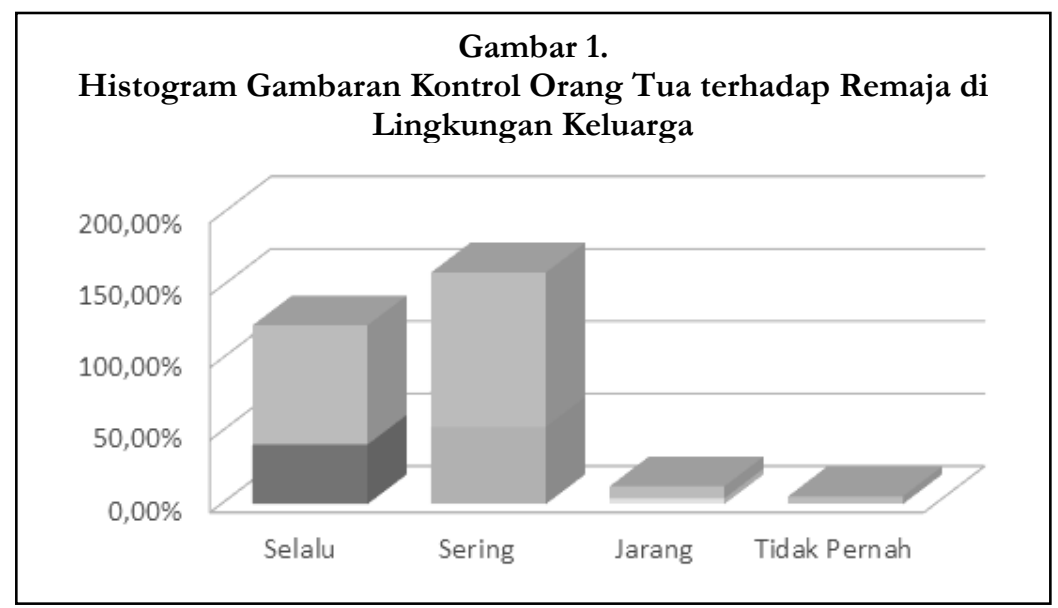

Hasil histogram pada Gambar 1. dapat dilihat jawaban responden menyatakan sering yang mana sering dikategorikan baik, hal ini terlihat dari rata-rata persentase jawaban 
responden sebanyak $(52,8 \%)$ orang tua menyatakan sering dalam melakukan kontrol, artinya orang tua sudah melaksanakan kontrol yang baik terhadap anaknya.

\section{Gambaran Dukungan Orang Tua terhadap Remaja di Lingkungan Keluarga}

Untuk melihat gambaran dukungan orang tua terhadap remaja di lingkungan keluarga, dapat dilihat pada Gambar 2.

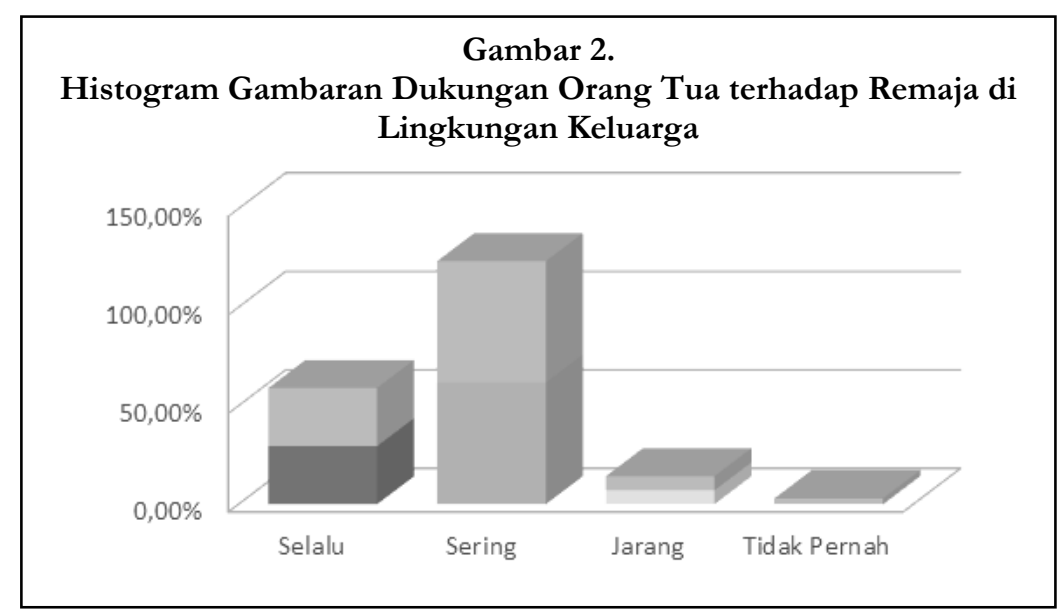

Hasil histogram pada Gambar 2. dapat dilihat jawaban responden menyatakan sering yang mana sering dikategorikan baik, hal ini terlihat dari rata-rata persentase jawaban responden sebanyak $(67,91 \%)$ orang tua menyatakan sering memberikan dukungan terhadap remaja di lingkungan, artinya orang tua sudah memberikan dukungan yang baik terhadap anak.

\section{Gambaran Komunikasi Orang Tua terhadap Remaja di Lingkungan Keluarga}

Untuk melihat gambaran komunikasi orang tua di lingkungan keluarga terhadap remaja dapat dilihat pada Gambar 3.

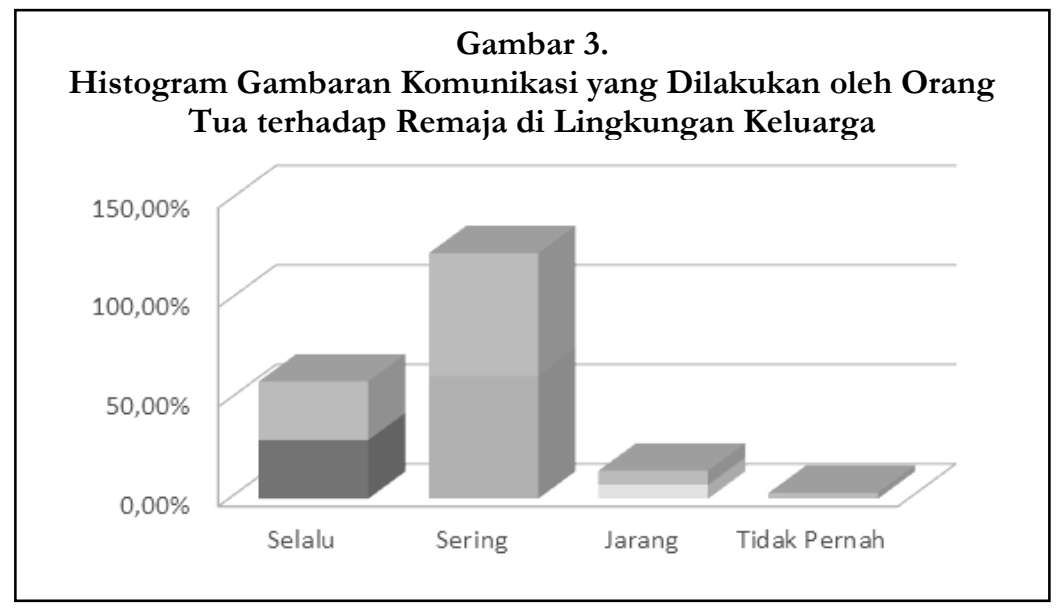

Berdasarkan histogram pada Gambar 3. di atas dapat dilihat jawaban responden menyatakan sering yang mana sering dikategorikan baik, hal ini terlihat dari rata-rata 
Gambaran Perilaku Pengasuhan Remaja oleh Orang Tua di Lingkungan Keluarga

persentase jawaban responden sebanyak (61,73\%) orang tua menyatakan sering melakukan komunikasi terhadap remaja di lingkungan keluarga, artinya orang tua sudah melakukan komunikasi yang baik terhadap anaknya.

\section{Gambaran Kedekatan Orang Tua terhadap Remaja di Lingkungan Keluarga}

Untuk melihat kedekatan orang tua terhadap remaja di lingkungan keluarga, dapat dilihat pada Gambar 4.

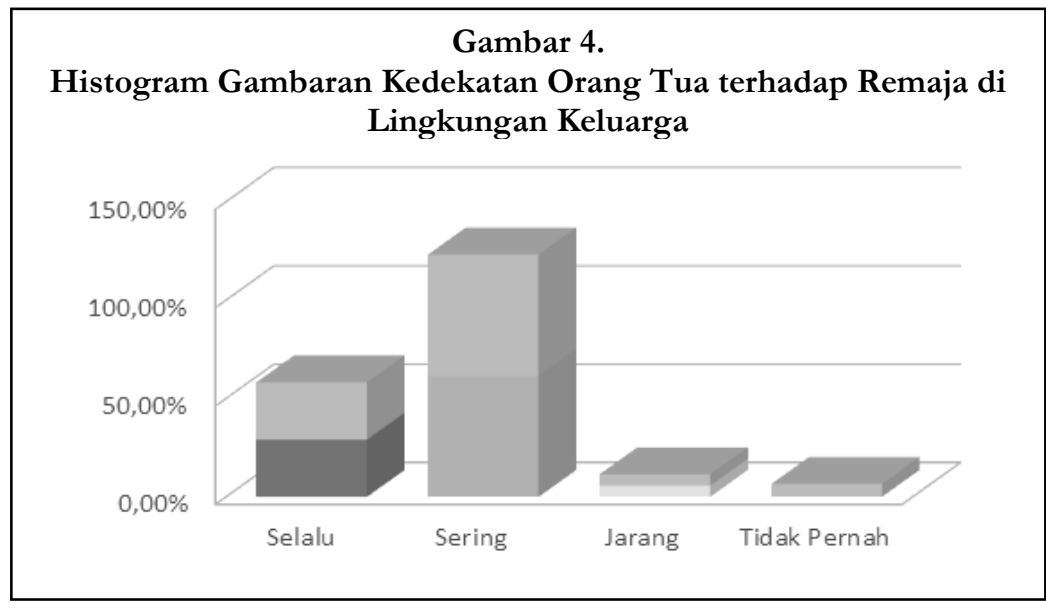

Berdasarkan histogram pada Gambar 4. dapat dilihat jawaban responden menyatakan sering yang mana sering dikategorikan baik, hal ini terlihat dari rata-rata persentase jawaban responden sebanyak $(61,68 \%)$ orang tua menyatakan sering melakukan kedekatan terhadap remaja di lingkungan keluarga, artinya orang tua sudah melakukan kedekatan yang baik terhadap anaknya.

\section{Gambaran Pendisiplinan Orang Tua terhadap Remaja di Lingkungan Keluarga}

Untuk melihat gambaran pendisplinan orang tua terhadap remaja di lingkungan keluarga, dapat dilihat pada Gambar 5.

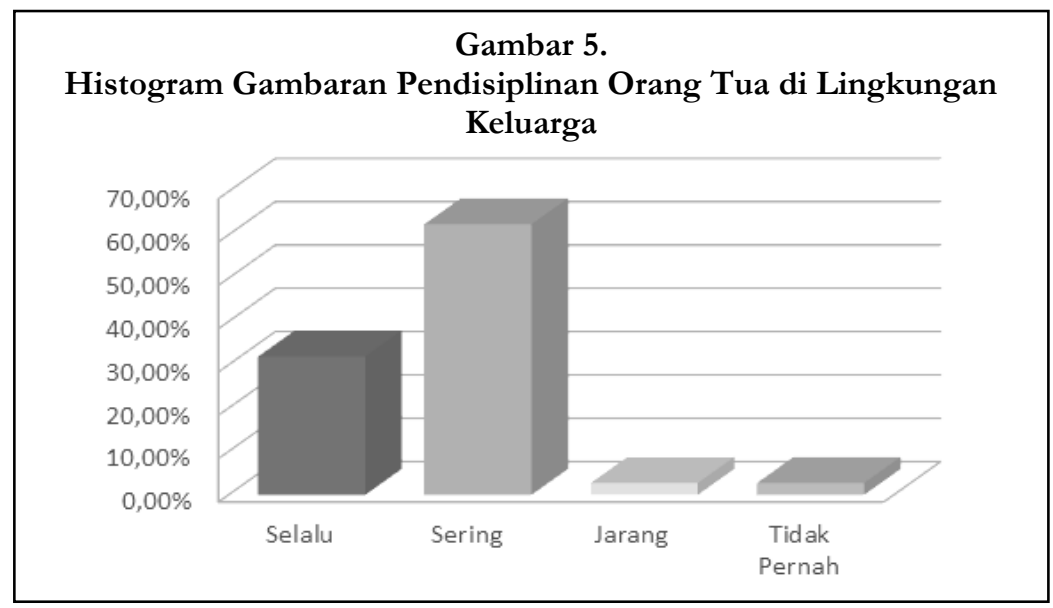


Berdasarkan histogram pada Gambar 5. dapat dilihat jawaban responden menyatakan sering yang mana sering dikategorikan baik, hal ini terlihat dari rata-rata persentase jawaban responden sebanyak $(62,51 \%)$ orang tua menyatakan sering melakukan pendisiplinan terhadap remaja di lingkungan keluarga, artinya orang tua sudah melakukan pendisiplinan yang baik terhadap anaknya.

\section{Pembahasan}

Berikut akan dipaparkan pembahasan hasil penelitian mengenai Gambaran Perilaku Pengasuhan Remaja oleh orang tua di lingkungan keluarga di Jorong Tanjung Betung Kecamatan Rao Selatan Kabupaten Pasaman

\section{Gambaran Kontrol Orang Tua terhadap Remaja di Lingkungan Keluarga}

Berdasarkan hasil pengolahan data tentang gambaran kontrol orang tua terhadap remaja di lingkungan keluarga, hal ini ditandai sebagian besar responden yang menyatakan sering pada butir pernyataan yang telah disediakan peneliti, untuk jawaban sering dikategorikan baik. Jadi berdasarkan data di atas menunjukkan bahwa gambaran kontrol oleh orang tua terhadap remaja di lingkungan keluarga berada pada kategori baik di Jorong Tanjung Betung, Kecamatan Rao Selatan, Kabupaten Pasaman.

Menurut Baldwin (dalam Lestari, 2012), menyatakan bahwa kontrol diartikan sebagai penekanan terhadap adanya batasan-batasan terhadap perilaku yang disampaikan secara jelas kepada anak dalam mengajarkan hal-hal yang benar. Kontrol sering diartikan sebagai mengawasi setiap kegiatan yang dilakukan oleh seorang anak dan memperhatikan perilaku anak. Kontrol yang dilakukan oleh orang tua di rumah terlaksana dengan baik, sejalan dengan pendapat ahli terlihat bahwa orang tua mengajarkan anak berperilaku baik sehingga perilaku anak berubah menjadi baik, dan orang tua memberikan perhatian kepada anak sehingga anak mengetahui apa yang dilakukannya dan peduli terhadap orang lain. Jadi dapat disimpulkan bahwa penelitian mengenai gambaran kontrol orang tua terhadap remaja di lingkungan keluarga dikatakan baik. Hal ini terlihat dari orang tua dapat memperhatikan perilaku anak, orang tua mengawasi aktivitas yang dilakukan anak,dan orang tua mengajarkan hal-hal yang benar kepada anak.

\section{Gambaran Dukungan Orang Tua terhadap Remaja di Lingkungan Keluarga}

Berdasarkan hasil pengolahan data tentang gambaran dukungan orang tua terhadap remaja di lingkungan keluarga, hal ini ditandai sebagian besar responden yang menyatakan sering pada butir pernyaatan yang disediakan peneliti, untuk jawaban sering dikategorikan baik. Jadi berdasarkan data di atas menunjukkan bahwa gambaran dukungan oleh orang tua terhadap remaja di lingkungan keluarga berada pada kategori baik di Jorong Tanjung Betung, Kecamatan Rao Selatan, Kabupaten Pasaman.

Orang tua diharapkan dapat memberikan dukungan kepada anak untuk mengembangkan kemampuan yang dimilikinya, belajar mengambil inisiatif, mengambil keputusan mengenai apa yang ingin dilakukan dan belajar, mempertanggungjawabkan segala perbuatannya. Menurut Thomas \& Rollins (dalam Lestari, 2012), menyatakan dukungan orang tua sebagai interaksi yang dikembangkan orang tua kepada anak yang dicirikan oleh perawatan, kehangatan, persetujuan, dan perasaan positif orang tua terhadap anak. Sehingga dengan adanya dukungan orang tua dapat membantu anak dalam menyelesaikan masalah, menentukan pilihan, memberikan nasehat kepada orang lain dalam pengambilan keputusan. 
Sejalan dengan hal tersebut dukungan dapat diartikan sebagai bentuk perlakuan dari orang tua terhadap remaja, memiliki ciri tersendiri dan berperan penting untuk mendorong dan mengarahkan anak sehingga anak berbuat sesuai norma yang berlaku dan yang kita inginkan.

Berdasarkan pendapat ahli di atas, bahwa dukungan orang tua terhadap remaja di lingkungan keluarga telah terlaksana dengan baik. Hal ini terlihat dari orang tua menyediakan fasilitas yang dapat menunjang pengetahuan anak, orang tua membnantu anak dalam menghadapi dan orang tua mengingatkan anak untuk berpikir terlebih dahulu sebelum bertindak, dan orang tua mengajarkan anak untuk meminta pendapat.

\section{Gambaran Komunikasi Orang Tua terhadap Remaja di Lingkungan Keluarga}

Berdasarkan hasil pengolahan data tentang gambaran komunikasi orang tua terhadap remaja di lingkungan keluarga, hal ini ditandai sebagian besar responden yang menyatakan sering pada butir pernyataan yang disediakan oleh peneliti, untuk jawaban sering dikategorikan baik. Jadi berdasarkan data di atas menunjukkan bahwa gambaran komunikasi oleh orang tua terhadap remaja di lingkungan keluarga berada pada kategori baik di Jorong Tanjung Betung, Kecamatan Rao Selatan, Kabupaten Pasaman.

Perilaku seorang anak khususnya remaja tidak terlepas dari komunikasi yang dilakukan dalam keluarga terutama orang tua. Ross (dalam Engkoswara \& Komariah, 2011), mendefinisikan komunikasi sebagai suatu proses menyortir, memilih, dan mengirimkan simbol-simbol sedemikian rupa, sehingga membantu penggemar membangkitkan makna atau respon dari pikirannya yang serupa dengan yang dimaksudkan oleh sang komunikator. Sesuai dengan pendapat ahli, Djamarah (2004), menyatakan keinginan anak untuk berbicara dengan orang tuanya dari hati ke hati melahirkan komunikasi interpersonal. Komunikasi dilandasi oleh kepercayaan anak kepada orang tuanya. Dengan kepercayaan itu, anak berusaha membangun keyakinan untuk membuka diri bahwa orang tuanya dapat dipercaya dan sangat mengerti perasaannya. Menjadi pendengar yang baik dan selalu membuka diri untuk berdialog dengan anak adalah langkah awal dalam mengakrabkan hubungan antara orang tua dan anak. Dengan begitu, anak tidak menganggap orang tuanya adalah orang yang tidak mengerti perasaan anak.

Sejalan dengan penjelasan para ahli tersebut bahwa gambaran komunikasi orang tua terhadap remaja di lingkungan keluarga terlaksana dengan baik. Hal tersebut terlihat dari orang tua bersedia mendengarkan pendapat yang diajukan anak, dan orang tua bisa merasakan apa yang dialami sang anak ketika anak dalam masalah. Jadi dapat disimpulkan bahwa penelitian mengenai gambaran komunikasi orang tua terhadap remaja di lingkungan keluarga sudah dikatakan baik, terlihat dari orang tua menggunakan kata yang jelas, dan bahasa yang lembut ketika berbicara dengan anak, orang tua memiliki sifat keterbukaan dengan anak, dan orang tua sebagai pendengar yang baik bagi anak.

\section{Gambaran Kedekatan Orang Tua terhadap Remaja di Lingkungan Keluarga}

Berdasarkan hasil temuan dan hasil pengolahan data tentang gambaran kedekatan orang tua terhadap remaja di lingkungan keluarga, hal ini ditandai sebagian besar responden yang menyatakan sering pada butir pernyataan yang disediakan oleh peneliti. Jadi berdasarkan data di atas menunjukkan bahwa gambaran kedekatan oleh orang tua terhadap remaja di lingkungan keluarga berada pada kategori baik di Jorong Tanjung Betung, Kecamatan Rao Selatan, Kabupaten Pasaman. 
Menurut Laursen, dkk. (dalam Lestari, 2012), kedekatan mengisyaratkan adanya saling ketergantungan dan perasaan terhubung antara orang tua dan anak, orang tua sebagai teman anak ketika di rumah, orang tua menjalin hubungan yang baik dengan anak. Kedekatan merupakan aspek penting dalam kehangatan yang memprediksikan kepuasan pengasuhan dan keterlibatan anak dalam aktivitas keluarga. Kedekatan orang tua dan anak memberikan keuntungan secara tidak langsung, seperti yang diungkapkan Rodgers (dalam Lestari, 2012), yaitu bila tingkat kedekatan orang tua dengan anak tidak tinggi, maka remaja cenderung mempersepsikan pemantauan yang dilakukan oleh orang tua sebagai gangguan. Begitu juga sebaliknya, bila ada rasa saling percaya antara orang tua dan anak apabila maka remaja mempersepsikan pemantauan yang dilakukan orang tua kepada anak merupakan salah satu bentuk perhatian orang tua kepada anak.

Sejalan dengan penjelasan ahli tersebut bahwa gambaran kedekatan yang dilakukan oleh orang tua terhadap remaja di lingkungan keluarga terlaksana dengan baik. Hal itu terlihat dari orang tua menciptakan suasana yang nyaman ketika dengan anak di rumah, dan orang tua menunjukkan kekompakan dengan anak dalam melakukan kegiatan. Jadi dapat disimpulkan penelitian mengenai gambaran kedekatan orang tua terhadap remaja di lingkungan keluarga sudah dikatakan baik. Hal ini terlihat dari orang tua sebagai teman di dalam keluarga, orang tua menjalin hubungan yang baik dengan anak.

\section{Gambaran Pendisiplinan Orang Tua terhadap Remaja di Lingkungan Keluarga}

Berdasarkan hasil pengolahan data tentang gambaran pendisiplinan orang tua terhadap remaja di lingkungan keluarga, hal ini ditandai sebagian besar responden yang menyatakan sering pada butir pernyataan yang disediakan oleh peneliti, untuk jawaban sering dikategorikan baik. Jadi berdasarkan data di atas menunjukkan bahwa gambaran pendisiplinan oleh orang tua terhadap remaja di lingkungan keluarga berada pada kategori baik di Jorong Tanjung Betung, Kecamatan Rao Selatan, Kabupaten Pasaman.

Menurut Wayson (dalam Shochib, 2010), disiplin adalah suatu tata tertib yang dapat mengatur tatanan kehidupan pribadi dan kelompok yang berdasarkan pada nilai agama, nilai budaya, aturan-aturan pergaulan, pandangan hidup, dan sikap hidup yang bermakna bagi dirinya sendiri, masyarakat, bangsa dan negara. Disiplin timbul dari jiwa karena adanya dorongan untuk mentaati tata tertib tersebut. Makna kata disiplin dapat dipahami dalam kaitannya dengan latihan yang memperkuat, koreksi dan sanksi, kendali atau terciptanya ketertiban dan keteraturan dan sistem aturan tata laku. Pelaksanaan disiplin ini juga perlu suatu ganjaran atau hukuman dalam suatu penegakan disiplin tersebut dapat berjalan dengan maksimal. Jadi dapat disimpulkan bahwa orang tua yang melakukan disiplin kepada anak merupakan salah satu upaya orang tua untuk membuat anak mematuhi peraturan yang ada di rumah

Sejalan dengan penjelasan ahli tersebut bahwa gambaran pendisiplinan orang tua terhadap remaja di lingkungan keluarga terlaksana dengan baik. Hal tersebut terlihat dari orang tua mengharuskan anak untuk mengikuti peraturan yang telah ditetapkan di rumah, orangtua mengajarkan anak untuk mengerjakan segala pekerjaan yang berhubungan dengan aturan rumah. Dari penjelasan di atas dapat disimpulkan bahwa pendekatan orang tua dengan anak dikatakan baik, hal itu terlihat dari menaati peraturan yang telah dibuat orang tua di rumah, menjalani peraturan yang telah ada. 


\section{KESIMPULAN}

Berdasarkan hasil penelitian dan pembahasan mengenai perilaku pengasuhan remaja di lingkungan keluarga pembentukan di Jorong Tanjung Betung, Kecamatan Rao Selatan, Kabupaten Pasaman pada bab sebelumnya dapat dikemukakan kesimpulan sebagai berikut: (1) gambaran kontrol orang tua terhadap remaja di lingkungan keluarga di Jorong Tanjung Betung, Kecamatan Rao Selatan, Kabupaten Pasaman telah terlaksana dengan baik. Terlihat dari orang tua memperhatikan semua perilaku anak di rumah terlaksana dengan baik, mengawasi aktivitas yang dilakukan oleh anak dan orang tua mengajarkan hal-hal yang benar kepada anak. (2) gambaran dukungan orang tua terhadap remaja di lingkungan keluarga di Jorong Tanjung Betung, Kecamatan Rao Selatan, Kabupaten Pasaman telah terlaksana dengan baik. Terlihat dari orang tua membantu anak dalam menyelesaikan masalah, orang tua mengajarkan anak dalam menetukan pilihan, orang tua memberikan nasehat kepada anak, orang tua tua menyediakan sarana dan prasarana yang dapat menunjang kebutuhan anak. (3) gambaran komunikasi orang tua terhadap remaja di lingkungan keluarga di Jorong Tanjung Betung, Kecamatan Rao Selatan, Kabupaten Pasaman telah terlaksana dengan baik. Terlihat dari Orang tua menggunakan kata yang jelas, dan bahasa yang lembut ketika berbicara dengan anak, orang tua memiliki sifat keterbukaan kepada anak, orang tua sebagai pendengar yang baik bagi anak, (4) gambaran kedekatan orang tua terhadap remaja di lingkungan keluarga di Jorong Tanjung Betung, Kecamatan Rao Selatan, Kabupaten Pasaman telah terlaksana dengan baik. Terlihat dari orang tua sebagai teman di dalam keluarga, orang tua menjalin hubungan yang baik dengan anak, dan (5) gambaran Pendisiplinan orang tua terhadap remaja di lingkungan keluarga di Jorong Tanjung Betung, Kecamatan Rao, Selatan Kabupaten Pasaman telah terlaksana dengan baik. Terlihat dari menaati peraturan yang dibuat oleh orang tua, menjalani peraturan yang telah ada.

\section{DAFTAR RUJUKAN}

Djamarah, S. B. (2004). Pola Komunikasi Orang Tua dan Anak Dalam Keluarga. Jakarta: PT Rineka Cipta.

Elly, R. (2016). Hubungan Kedisiplinan Terhadap Hasil Belajar Siswa Kelas V di SD Negeri 10 Banda Aceh. Jurnal Pesona Dasar, 3(4), 43-53.

Engkoswara, \& Komariah. (2011). Administrasi Pendidikan. Bandung: Alfabeta.

Hedyanti, W. N., Sudarmiatin, \& Utaya, S. (2016). Pengaruh Pola Asuh Orang Tua Terhadap Prestasi Belajar IPS Melalui Motivasi Belajar. Jurnal Pendidikan, 1(5), 865-873.

Jailani, M. S. (2014). Teori Pendidikan Keluarga dan Tanggung Jawab Orang Tua dalam Pendidikan Anak Usia Dini. Nadwa Jurnal Pendidikan Islam, 8(2), 245260.

Lestari. (2012). Psikologi Keluarga. Jakarta: Kencana.

Muchith, M. S. (2015). Membangun Komunikasi Edukatif. AT-TABSYIR: Jurnal Komunikasi Penyiaran Islam, 3(1), 165-184.

Resty, G. T. (2016). Pengaruh Penerimaan Diri Terhadap Harga Diri Remaja di Panti Asuhan Yatim Piatu Aisyayah Yogyakarta. Jurnal Bimbingan Dan Konseling, 1(5).

Shochib, M. (2010). Pola Asub Orang Tua. Jakarta: Rineka Cipta. 
Soelaiman, J. (2004). Konsep Dasar Pendidikan Luar Sekolah. Jakarta: PT. Bumi Aksara. Vinayastri, A. (2015). Pengaruh Pola Asuh (Parenting) Orang Tua Terhadap Perkembangan Otak Anak Usia Dini. Jurnal Imiah WIDY A, 3(1), 33-42. 